\title{
Pemanfaatan Learning Management System (LMS) sebagai Pendukung Pembelajaran Online di SMK Syafi'i Akrom Pekalongan
}

\author{
Danang Wahyu Utomo ${ }^{1}$, Defri Kurniawan ${ }^{2}$, Ramadhan Rakhmat Sani ${ }^{3}$, Yani Parti Astuti ${ }^{4}$ \\ ${ }^{1,2,3,4}$ Teknik Informatika Fakultas Ilmu Komputer Universitas Dian Nuswantoro \\ E-mail: ${ }^{1}$ danang.wu@dsn.dinus.ac.id, ${ }^{2}$ defri.kurniawan@dsn.dinus.ac.id, \\ ${ }^{3}$ ramadhan_rs@dsn.dinus.ac.id, ${ }^{4}$ yani.parti.astuti@dsn.dinus.ac.id
}

\begin{abstract}
Abstrak
SMK Syafi'i Akrom Pekalongan adalah salah satu lembaga pendidikan vokasi yang menyediakan pendidikan dengan kurikulum nasional. Pada masa pandemi covid19, SMK Syafi'i Akrom berperan dalam menerapkan pembelajaran secara daring. Namun, beberapa guru masih ada yang kesulitan dalam menerapkan pembelajaran secara online. Menurut Wakil Kepala Sekolah bidang Kurikulum menyatakan bahwa beberapa guru masih kesulitan dalam menggunakan aplikasi Learning Management System guna mendukung pembelajaran online. Berdasarkan permasalahan tersebut, pengabdian masyarakat ditujukan untuk memberikan pendampingan bagi guru - guru dalam menggunakan aplikasi LMS yaitu Edmodo. Target utama adalah para guru mampu mengetahui tata cara penggunaan LMS Edmodo.
\end{abstract}

Kata kunci: e-learning, learning management system, SMK Syafi'i Akrom

\begin{abstract}
SMK Syafi'i Akrom Pekalongan is one of the vocational institutions that provide education using the national curriculum. During a covid19 pandemic, SMK Syafi'i Akrom has a role to apply the learning as online. However, some teachers have difficulty to implement online learning. According to the vice-headmaster curriculum stated that some teachers still has difficulty using LMS application to support online learning. Based on the problem above, the society service aims to assist the teacher to use the LMS application that is Edmodo. The main target is the teachers can know the use of LMS Edmodo.
\end{abstract}

Keywords: e-learning, learning management system, SMK Syafi'i Akrom

\section{PENDAHULUAN}

Sekolah Menengah Kejuruan (SMK) Syafi'i Akrom Pekalongan bertempat di Jl. Pelita I No.332, Perumahan Buaran Indah, Pekalongan didirikan berdasarkan kesepakatan kerjasama Lembaga Pendidikan Ma'arif NU Kota Pekalongan dengan Yayasan Pondok Pesantren AlQur'an Buaran dengan bantuan Direktorat Pendidikan Menengah Kejuruan, Depdiknas RI berdasarkan Rekomendasi Kanwil Depag Provinsi Jawa Tengah[1]. Dalam hal ini, SMK Syafi'i Akrom menyelenggarakan pendidikan formal dengan kurikulum nasional.

SMK Syafi'i Akrom merupakan sekolah yang memadukan pemahaman ilmu agama dengan sains. Adanya sekolah ini diharapkan dapat memunculkan generasi muda yang tidak hanya paham agama namun juga mampu menjawab tantangan zaman terutama pada sains. Perkembangan sains atau ilmu pengetahuan tidak terlepas dari perkembangan teknologi informasi. Perkembangan teknologi informasi memberikan kemudahan bagi masyarakat umum dalam segala aspek. Terutama pada bidang pendidikan, teknologi informasi mampu memberikan kemudahan bagi guru dan siswa dalam menunjang pembelajaran interaktif. Salah 
satu contoh adalah e-learning yang memberikan fasilitas bagi guru dan siswa untuk tetap menjalankan proses belajar mengajar secara interaktif meskipun tanpa tatap muka. Menurut R. Yunis [2], e-learning dapat menyesuaikan kebutuhan pembelajaran yang dilakukan oleh SMK maupun SMA seperti penugasan, penilaian, dan ujian akhir. Bagi siswa, e-learning memberikan keuntungan diskusi efektif kepada guru dan temannya. Siswa dapat membahas materi dengan temannya tanpa terbatas oleh waktu. E-learning memberikan keleluasaan dalam belajar yang mampu digunakan kapanpun dan dimanapun.

Seiring berkembangnya revolusi industry 4.0, banyak aplikasi yang diusulkan untuk menunjang pembelajaran interaktif guru dengan siswanya menggunakan konsep e-learning. Learning Management System (LMS) adalah salah satu perangkat lunak berbasis daring yang memberikan fasilitas pembelajaran jarak jauh. LMS saat ini mampu memfasilitasi pembelajaran daring dengan menunjang pengajaran dan pembelajaran yang menyediakan sarana komunikasi bagi guru dan siswa [3]. Dalam model pembelajaran jarak jauh, para guru dapat mengajar seperti halnya di kelas dimana mencakup tanya jawab, tugas kelompok, koreksi tugas, dan penyelenggaraan ujian akhir sekolah. Ramadhan menyatakan [4], e-learning mampu memberikan inovasi pembelajaran dengan mengikuti perkembangan teknologi dengan tujuan agar siswa mampu menggunakan perkembangan teknologi sebagai bahan penunjang kegiatan belajar.

Pada masa pandemi covid 19, pembelajaran di kelas diubah menjadi pembelajaran secara daring [5]. Para guru dan siswa melakukan kegiatan belajar mengajar secara online untuk mengurangi penyebaran virus tersebut. Pembelajaran daring (pembelajaran jarak jauh) yang saat ini dijalankan oleh SMK Syafi'i Akrom hanya sebatas guru memberikan penugasan ke siswa melalui whatsapp grup, siswa melakukan pengumpulan tugas melalui grup tersebut dan evaluasi akan dilakukan pada pertemuan selanjutnya. Model pembelajaran jarak jauh tersebut dapat merugikan siswa karena jarang mendapat umpan balik langsung dari guru terkait materi dan penugasan yang diberikan. Lambatnya evaluasi dan umpan dari guru disebabkan karena guru tidak langsung melakukan koreksi terhadap tugas yang dikumpulkan oleh siswa. Artinya, pengecekan tugas tidak dilakukan secara intensif. Selain itu, siswa tidak dapat mengetahui secara langsung hasil koreksi dari tugas yang telah dikerjakan. Akibatnya, siswa tidak mengetahui apakah tugas yang dikerjakan sudah tepat atau belum.

Berdasarkan permasalahan diatas, maka dilakukan pengabdian kepada masyarakat di SMK Syafi'i Akrom guna melakukan pendampingan terhadap guru - guru dalam menggunakan LMS. Materi yang disampaikan pada pengabdian masyarakat mengenai konsep LMS dan tata cara penggunaan aplikasi LMS yaitu Edmodo. Target utama dari pengabdian masyarakat ini adalah para guru mampu menggunakan aplikasi LMS dalam menunjang pembelajaran jarak jauh dan selanjutnya mampu menerapkan LMS Edmodo ke dalam proses belajar mengajar di SMK Syafi'i Akrom.

\section{METODE PELAKSANAAN}

Metode pelaksanaan terdiri dari 3 (tiga) tahap yaitu tahap persiapan, tahap pelaksanaan, dan tahap akhir.

Tahap pertama (tahap persiapan) pelaksanaan pengabdian masyarakat adalah koordinasi dengan pihak SMK Syafi'i Akrom. Tim pengabdian masyarakat melakukan koordinasi dengan wakil kepala sekolah bidang kurikulum untuk menentukan topik permasalahan, materi pengabdian masyarakat, teknis pelaksanaan, jumlah peserta dan penentuan alat dan bahan yang menunjang pelaksanaan kegiatan.

Tahap kedua (tahap pelaksanaan), tim pengabdian melakukan pembagian tugas berupa persiapan materi, alat dan bahan yang akan digunakan dalam pengabdian masyarakat. Karena kegiatan dilaksanakan pada masa pandemi yaitu pada bulan Juli 2020, maka pembagian materi dan pelaksaanaan kegiatan dilakukan secara daring yaitu melalui google meet. Sarana yang disiapkan oleh pihak sekolah untuk mendukung pengabdian secara daring adalah LCD proyektor, laptop, dan akses internet yang memadai bagi peserta. Pelaksanaan pengabdian 
terdiri dari penyampaian materi oleh tim pengabdian, pelatihan penggunaan Edmodo, dan sesi tanya jawab untuk membantu peserta dalam memahami materi tentang penggunaan Edmodo.

Tahap ketiga (tahap akhir), dokumentasi pengabdian masyarakat yaitu dengan melakukan perekaman pelaksanaan program pengabdian masyarakat di google meet. Hasil dari rekaman tersebut digunakan sebagai bahan penyusunan laporan akhir dan pembuatan video dokumentasi yang akan diunggah pada media youtube.

\section{HASIL DAN PEMBAHASAN}

Sesuai dengan target utama bahwa pada pengabdian masyarakat ini, para guru mengetahui tata cara penggunaan aplikasi LMS yaitu Edmodo. Maka, pada pengabdian masyarakat ini materi yang digunakan membahas seputar Edmodo dan bagaimana cara menggunakannya. Penyampaian materi pengabdian masyarakat terbagi menjadi 3 sesi yaitu: sesi 1 tentang pengenalan LMS dan Edmodo, sesi 2 tentang materi dan penugasan, dan sesi 3 tentang penggunaan Edmodo melalui mobile.

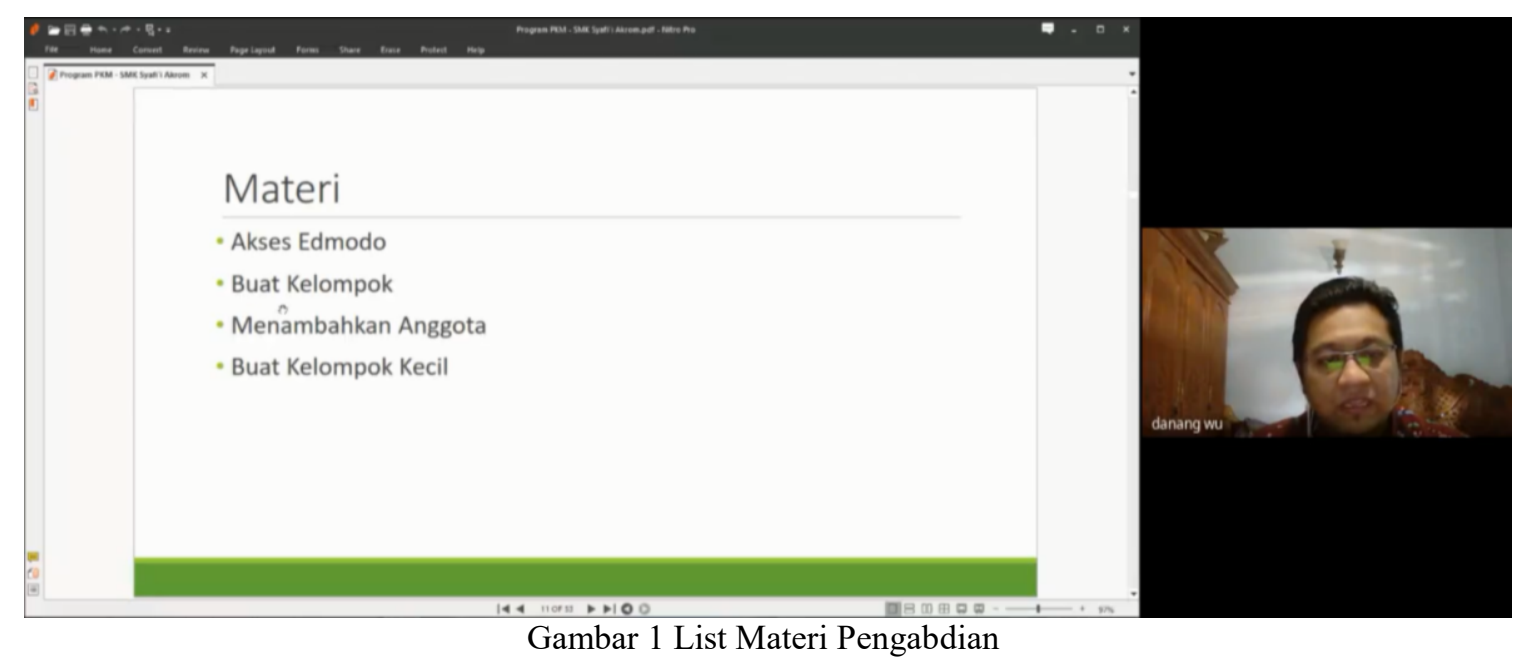

Pada gambar 1, pemateri pertama dari tim pengabdian masyarakat membahas tentang bagaimana melakukan akses halaman Edmodo khususnya pada halaman guru, bagaimana cara membentuk kelompok dan menambahkan anggota. Pada sesi ini, pemateri fokus pada materi awal penggunaan aplikasi Edmodo yaitu pengaksesan melalui website dan penggunaannya melalui web Edmodo. Selanjutnya, komposisi dasar dalam pembelajaran yaitu adalah belajar kelompok. Kendala yang dihadapi oleh para guru adalah pemberian tugas kelompok secara daring. Beberapa guru masih menggunakan whatsapp dalam memberikan tugas kepada siswa. Permasalahan yang dihadapi adalah siswa sering terlambat dalam menanggapi tugas yang diberikan, guru kesulitan melakukan koreksi tugas siswa karena harus melakukan scrolling satu per satu tugas yang dikumpulkan dalam grup WA. Permasalahan selanjutnya adalah tugas kelompok yaitu para guru kesulitan dalam mengevaluasi kinerja siswa dalam kelompok. Guru tidak mengetahui siswa yang mengerjakan bagian tugas dalam kelompoknya. LMS Edmodo memberikan fitur tugas kelompok untuk mengatasi permasalahan tersebut. Materi pelatihan yang diberikan adalah bagaimana mengatur pembelajaran secara kelompok secara daring, bagaimana cara membuat kelompok dan menambahkan siswa ke dalam kelompok tersebut. Tujuan dari materi ini agar para guru dapat mempersiapkan kondisi kelas dan siswa jika menerapkan pembelajaran kelompok. Adanya pengaturan kelompok siswa, guru dapat memantau keaktifan siswa dalam kelompok tersebut. 


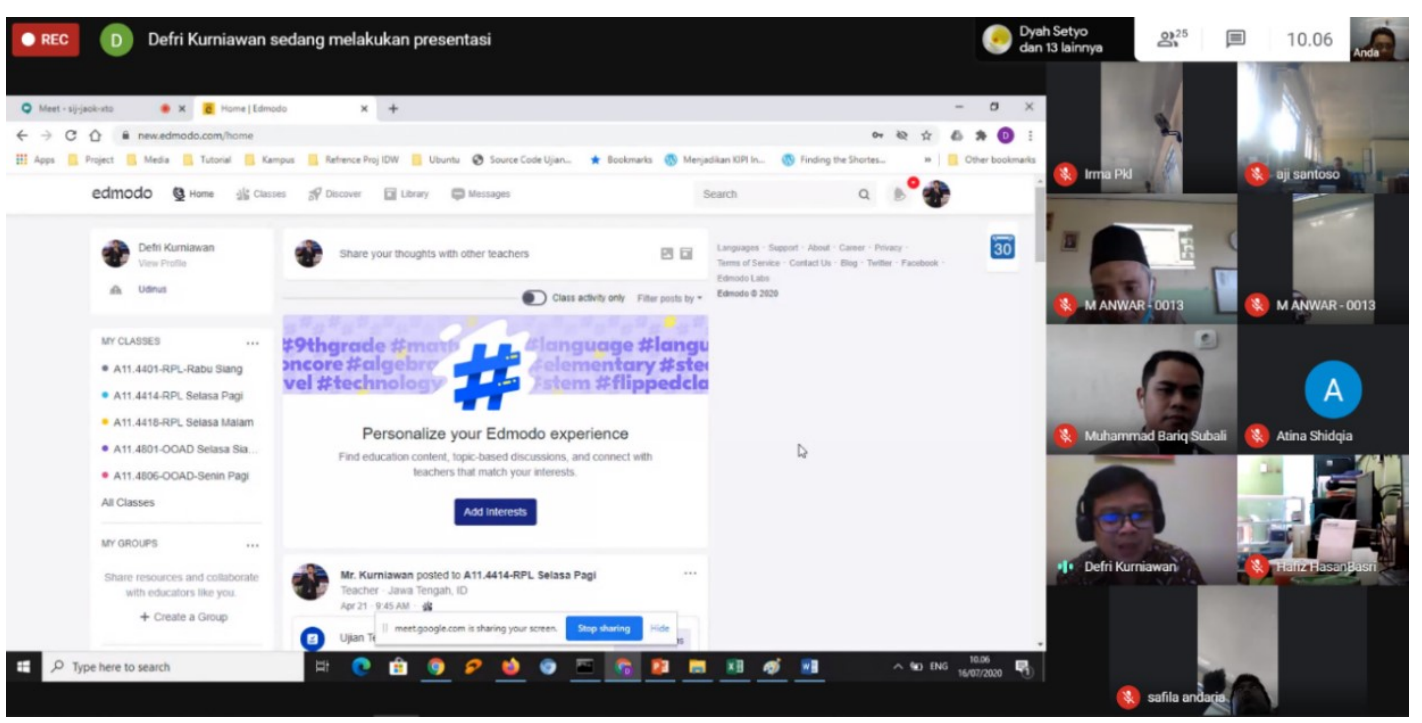

Gambar 2 Sharing Materi

Pemateri kedua membahas tentang pemberian (sharing) materi pada halaman Edmodo dan pengaturan penugasan. Pada sesi ini (Gambar 2), pemateri menjelaskan bagaimana cara melakukan pemberian materi kepada siswa, jenis file apa saja yang dapat di unggah pada halaman Edmodo, dan tata cara bagaimana siswa dapat mengakses materi tersebut. Salah satu fitur yang menunjang keaktifan siswa adalah form penugasan. Fokus utama dari pemateri adalah bagaimana cara memberikan penugasan efektif kepada siswanya di masa pandemi. LMS Edmodo memberikan fitur pengaturan penugasan baik tugas kelompok maupun tugas individu. Para guru dapat mengatur format pengumpulan tugas seperti: kapan tugas harus dikumpulkan (due date), kapan tugas tersebut dijadwalkan (schedule), dan kepada siapa tugas tersebut diberikan. Jika, para guru mengampu lebih dari 1 kelas, maka pengaturan assign to memudahkan guru untuk memberikan penugasan kepada kelas atau kelompok kelas yang dituju (Gambar 3).

\section{Pengaturan Penugasan}

Kemudian, Edmodo akan menampilkan form berupa bentuk penugasan yang akan diberikan kepada siswa, jadwal penugasan, dan file - file yang sekiranya diperlukan dalam mendukung penugasan

Klik Create

Hasilnya dapat dilihat pada postingan awal beranda kelas

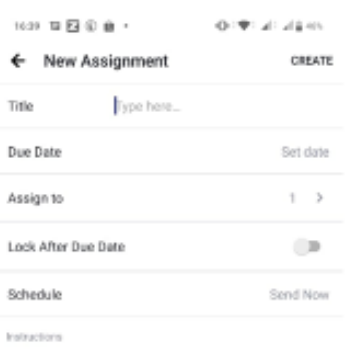

add attachment

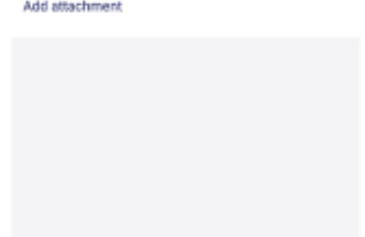


Pada sesi ketiga, pemateri menyampaikan penggunaan Edmodo versi mobile. Materi Edmodo versi mobile disampaikan karena saat ini banyak para guru telah memiliki smartphone. Pada sesi ini, materi Edmodo versi mobile disampaikan secara spesifik yaitu hanya mengambil contoh pemberian penugasan melalui mobile dan bagaimana cara mengakses penugasan tersebut via mobile. Pada gambar 3, menunjukkan pemberian penugasan melalui mobile. Materi menampilkan form penugasan pada Edmodo versi mobile. Tujuan dari penyampaian materi ini adalah para guru dapat mengontrol aktivitas belajar siswa secara real time karena LMS Edmodo dapat memberikan notifikasi terkait pengumpulan tugas, diskusi materi, dan pertanyaan pertanyaan yang diajukan oleh siswa. Adanya fitur tersebut memudahkan para guru untuk memantau siswa yang aktif dan pasif dalam mengumpulkan tugas dan diskusi tiap pertemuan. Selain itu, guru dapat secara langsung memberikan tanggapan kepada siswa jika ada pertanyaan - pertanyaan yang diajukan.

Pada sesi terakhir yaitu sesi tanya jawab, peserta mengajukan beberapa pertanyaan terkait permasalahan yang dihadapi saat melakukan pembelajaran formal dan pembelajaran melalui daring. Berikut beberapa pertanyaan yang dibahas pada sesi tanya jawab:

Tabel 1 Daftar Pertanyaan Peserta

\begin{tabular}{|c|l|}
\hline No & \multicolumn{1}{|c|}{ Pertanyaan } \\
\hline 1 & Bagaimana cara menambahkan anggota ke kelompok? \\
\hline 2 & Apakah porsi kelompok dapat berbeda dengan kelompok lain? \\
\hline 3 & Bagaimana cara memberikan penilaian terhadap tugas kelompok \\
\hline 4 & $\begin{array}{l}\text { Bagaimana cara memberikan penilaian otomatis terhadap hasil } \\
\text { ujian siswa? }\end{array}$ \\
\hline 5 & Bagaimana cara mengetahui rapor kerja siswa? \\
\hline
\end{tabular}

Berdasarkan pertanyaan yang diajukan oleh peserta pada Tabel 1, secara garis besar, permasalahan yang dihadapi oleh para guru adalah pemberian tugas kelompok, mengatur pembentukan kelompok secara daring dan memberikan evaluasi terhadap tugas kelompok tersebut. Dapat diambil kesimpulan bahwa kendala yang dihadapi oleh para guru adalah memberikan pembelajaran dengan model kelompok secara daring dan bagaimana cara melakukan evaluasinya. Adanya Edmodo sebagai salah satu aplikasi LMS memberikan kemudahan bagi para guru dalam menunjang aktivitas guru di kegiatan belajar mengajar. Salah satu materi yang diberikan pada pelatihan ini tidak hanya fokus pada bagaimana cara menggunakan LMS Edmodo sebagai pendukung belajar secara daring, namun juga memberikan solusi terkait penugasan siswa meliputi tugas individu dan tugas kelompok. Selain itu, materi yang diberikan juga tentang bagaimana melakukan evaluasi dan penilaian tugas siswa dalam LMS Edmodo.

Selain sesi tanya jawab, tim pengabdian masyarakat melakukan survey untuk mengetahui tingkat pemahaman dari para guru dalam menggunakan LMS Edmodo. Survey diberikan dalam bentuk kuesioner dengan model likert scale skala 5 yaitu Sangat Setuju, Setuju, Netral, Tidak Setuju, dan Sangat Tidak Setuju. Survey ditujukan untuk peserta yang mengikuti pengabdian masyarakat yaitu berjumlah 25 peserta. Berikut hasil survey:

Tabel 2. Hasil Survei

\begin{tabular}{|c|c|c|c|c|c|c|}
\hline \multirow[b]{2}{*}{ No } & \multirow[b]{2}{*}{ Topik Pertanyaan } & \multicolumn{5}{|c|}{ Tanggapan (\%) } \\
\hline & & $\begin{array}{l}\text { Sangat } \\
\text { Setuju }\end{array}$ & Setuju & Netral & $\begin{array}{c}\text { Tidak } \\
\text { Setuju }\end{array}$ & $\begin{array}{c}\text { Sangat } \\
\text { Tidak } \\
\text { Setuju }\end{array}$ \\
\hline 1 & Kemudahan penggunaan konten/menu/fitur pada edmodo & 40 & 60 & 0 & 0 & 0 \\
\hline 2 & Kemudahan sharing materi & 32 & 40 & 20 & 8 & \\
\hline 3 & Kesesuaian form penugasan dengan pembelajaran di kelas & 20 & 56 & 0 & 8 & 16 \\
\hline 4 & Kesesuaian pengaturan kelompok dengan pembelajaran di kelas & 40 & 40 & 20 & 0 & 0 \\
\hline 5 & Kesesuaian model evaluasi penugasan siswa & 48 & 40 & 0 & 12 & 0 \\
\hline 6 & Kemudahan dalam membuat bank soal & 12 & 64 & 20 & 4 & 0 \\
\hline 7 & Hasil evaluasi belajar siswa & 0 & 64 & 24 & 12 & 0 \\
\hline 8 & Kemudahan penggunaan Edmodo versi mobile & 8 & 48 & 32 & 0 & 12 \\
\hline
\end{tabular}


Berdasarkan Tabel 2, hasil survey menunjukkan bahwa diatas 50\% peserta menyatakan bahwa konten pada Edmodo mudah digunakan dan form penugasan pada LMS Edmodo sesuai dengan format yang diberikan pada pembelajaran dikelas. Dapat disimpulkan bahwa, para peserta setuju Edmodo mampu menunjang aktivitas belajar mengajar guru dan siswa. Hasil survey juga menunjukkan bahwa diatas $60 \%$ para guru setuju LMS Edmodo mampu memberikan kemudahan dalam membuat soal dan melakukan evaluasi hasil belajar siswa. Terbukti pada topik kuesioner no. 6, para guru setuju 64\% bahwa Edmodo memberikan kemudahan dalam pembuatan bank soal.

Berdasarkan analisis hasil survey diatas dapat diambil kesimpulan bahwa pelatihan penggunaan LMS Edmodo di SMK Syafi'i Akrom mampu memberikan solusi dan kemudahan bagi para guru dalam menunjang kegiatan belajar mengajar secara daring. Setelah dilakukan pelatihan, para guru mampu menggunakan LMS Edmodo yang dapat digunakan dalam mendukung pembelajaran secara daring. Selain itu, format pembelajaran seperti: penugasan, pengaturan kelompok, dan evaluasi hasil belajar siswa yang disediakan pada LMS Edmodo tidak berbeda dengan form pembelajaran dari SMK Syafi'i Akrom.

\section{KESIMPULAN DAN SARAN}

Berdasarkan pengabdian masyarakat dan hasil survey yang dilaksanakan, dapat disimpulkan bahwa pendampingan guru - guru SMK Syafi'i Akrom dalam menggunakan aplikasi LMS mampu membantu para guru melaksanakan pembelajaran daring sesuai dengan format pembelajaran di kelas. Hasil survey menunjukkan bahwa diatas 50\% para guru mampu menggunakan Edmodo terkait sharing materi, penugasan dan evaluasi siswa. Sehingga hasil dari pengabdian ini dapat digunakan oleh para guru untuk menunjang pembelajaran secara daring.

\section{DAFTAR PUSTAKA}

[1] D. P. K. Pekalongan, "Keputusan Kepala Dinas Pendidikan Kota Pekalongan,” 2005, p. 10.

[2] R. Yunis and K. Telaumbanua, "Pengembangan E-Learning Berbasiskan LMS untuk Sekolah, Studi Kasus SMA/SMK di Sumatera Utara," JNTETI, vol. 6, no. 1, pp. 32-36, 2017.

[3] K. Hakobyan, E. Golubovskaya, N. Mekeko, and M. Muzyka, "Learning Management System for Blended Learning in Teacher Education Through Teaching Staff and Students Perceptions," Aust. J. Teach Educ., vol. 43, no. 3, pp. 21-34, 2018.

[4] R. R. Sani, D. W. Utomo, and D. Kurniawan, "Penerapan Edmodo bagi Guru dan Murid SMK Karya Bhakti Brebes sebagai Media Belajar Tambahan," Abdimasku J. Pengabdi. Masy., vol. 3, no. 2, p. 34, 2020.

[5] E. Istikhoirini, "STUDI LITERATUR : EDMODO SEBAGAI MEDIA PEMBELAJARAN MATEMATIKA DARING DALAM ERA MERDEKA BELAJAR DI MASA PANDEMI," Semin. Nas. Pendidik. Mat., vol. 1, no. 1, pp. 11-18, 2021. 